University of Warwick institutional repository: http://go.warwick.ac.uk/wrap This paper is made available online in accordance with publisher policies. Please scroll down to view the document itself. Please refer to the repository record for this item and our policy information available from the repository home page for further information.

To see the final version of this paper please visit the publisher's website. Access to the published version may require a subscription.

Author(s): Margot C. Finn

Article Title: Colonial Gifts: Family Politics and the Exchange of Goods in British India, c. $1780-1820$

Year of publication: 2006

Link to published version: http://dx.doi.org/

10.1017/S0026749X06001739

Publisher statement: None 
Modern Asian Studies 4o, 1 (2006) pp. 203-231. (C) 2006 Cambridge University Press doi:10.1017/S0026749X06001739 Printed in the United Kingdom

\title{
Colonial Gifts: Family Politics and the Exchange of Goods in British India, c. $1780-I 820$
}

\author{
MARGOT G. FINN ${ }^{1}$
}

University of Warwick

In August 1851, James Russell travelled to London from his estate on the banks of the Tweed. As a young man decades earlier, Russell had served as a cavalry officer in India, and he was anxious to exploit this visit to the metropolis to renew his acquaintance with the men who had formed his social circle years ago in Hyderabad. Having arrived in London, James Russell called on Charles Russell (no relation) at the latter's residence in Argyle Street. Chairman of the Great Western Railway, Charles Russell too had passed his youth in India, serving as a lieutenant in the Company's army and as an assistant to the diplomatic Resident at Hyderabad-his older brother, Henry. In a letter to his brother-now Sir Henry and (thanks to his Indian fortune) the proprietor of an extensive landed estate in Berkshire-Charles described James Russell as 'still a great oddity, almost mad I think', but conceded that 'all his feelings are those of [a] gentleman and his pursuits have always been intellectual'. To substantiate this assessment of his old friend's sensibilities, he instanced James Russell's retention and use of a dictionary given to him by Charles in Hyderabad. 'He gratified me by telling me that he still retained "a handsome Greek Lexicon" which I gave him, when he resumed the study of Greek', Charles informed his brother Henry. 'On his way home [from India] he followed the retreat of the ten thousand

${ }^{1}$ This paper was originally presented at a workshop on 'Consumption, Modernity and the West' supported by the AHRB-ESRC Consumption project and the California Institute of Technology. Revised versions of the paper were delivered to the History Department seminar at the University of York and the Long Eighteenth Century Seminar, Institute of Historical Research, London. The author is grateful to the audiences of those meetings for their comments, criticisms and suggestions, and to John Brewer, Sarah Hodges, Josephine McDonagh and Frank Trentman for their close readings of earlier versions of the text.

oo26-749X/o6/\$7.50+\$0.10 
with Xenophon in his hand; and he has since worked hard, he tells me, at the Greek historians, poets \& dramatists'. ${ }^{2}$ Having reminisced in London with Charles, James Russell journeyed to Berkshire to visit Sir Henry Russell, who read excerpts from Charles's letter aloud to his guest. 'I always liked him', Sir Henry wrote to his brother upon James Russell's departure, 'and when I read to him your reference to early days, his eyes filled with tears'.

The record of James Russell's visit to his erstwhile Indian comrades alerts us to a series of associations among gift-giving, gentility, sociability, sentiment, memory and family that underpinned British imperial expansion in later eighteenth- and early nineteenth-century India. The Greek lexicon gifted by Charles Russell to James Russell in Hyderabad encapsulates a chain of transactions-at once economic and emotive-by which Anglo-Indian men and women established and maintained social and political relations across distance and time in the Romantic era. ${ }^{4}$ Gift-giving played a central role in the emotional economy of Anglo-Indian society in these decades. Acting to unite family members separated by oceans and continents, it also worked to create liens of political obligation between patrons and their clients within the British expatriate community. As the invocation of James Russell's 'handsome Greek lexicon' in the correspondence of Charles and Sir Henry Russell suggests, moreover, gifted items enjoyed an afterlife in the imperial imagination that could extend for decades beyond their initial transfer from donor to recipient. The circuits of sociability, affection and memory triggered by Charles Russell's gift surmounted substantial spatial, temporal and cultural boundaries. In India in the early years of the nineteenth century, Russell's dictionary had functioned to unite young men of the officer class both to each other and to the classical traditions of Greece that informed gentlemanly ideals in the British metropole-traditions from which their exile to the Orient had distanced these men as adolescents. In Britain decades later, the gifted Greek lexicon worked to activate

${ }^{2}$ Charles Russell to Sir Henry Russell, 19 August 1851, Bodleian Library, MS Eng. lett. e. 42 , fols. $138-139$ verso.

${ }^{3}$ Sir Henry Russell to Charles Russell, 28 August $185^{1}$, Bodleian Library, MS Eng. lett. e. $4^{2}$, fols. $14^{2-1} 4^{2}$ verso.

4 'Anglo-Indian' is used throughout this essay to denote British residents in India and their family members (in both India and Britain). For the structure and sentiments of the Anglo-Indian community in this period, see P. J. Marshall, 'British Society in India under the East India Company', Modern Asian Studies, 31, 1 (1997), pp. 89-108. 
shared memories of India in mature men now dispersed across Scotland, London and the Home Counties. Capable of collapsing space, time and alterity, the gift relation proved an essential instrument of colonial identity formation in British India throughout the period of Company rule.

This paper situates Anglo-Indian gifts within a spectrum of emotionally-charged exchange mechanisms through which material objects circulated in British India. At one end of this spectrum was the market, perhaps best exemplified by the public auctions at which the personal possessions of deceased Anglo-Indians were sold to any buyer who could pay the purchase price set at probate. At the other end of the spectrum of exchange were gifts, commissions and bequests, forms of exchange that offered the British colonial elite mechanisms for combating the powerful centrifugal forces that operated within Anglo-Indian families-most notably disease, death and distance. Such gifts are documented in dense detail in extant collections of Anglo-Indian family correspondence. The letters of three intertwined family networks are examined in this paper: the family of Sir Henry Russell (1751-1836), who served as Chief Justice of Bengal early in the nineteenth century; the family of James Casamaijor (fl. 180513), a member of the governing Council of Madras; and the family of Gilbert Elliot (1751-1814), first Earl of Minto and Governor General of India from 1807 to 1813 . Together with probate inventories that chronicle the sale of personal possessions at public auctions, these records provide a window onto the affective and strategic uses of Anglo-Indian material goods.

The gift-giving and market-orientated consumer behaviours detailed in this paper occupied shifting positions within a fluid register of exchange in Anglo-India, rather than representing alternative, distinctively 'pre-modern' and 'modern' mechanisms for the circulation of honour, obligation and goods. ${ }^{5}$ In both Britain and India, gift-giving practices played a vital role in political relations, and the body figured centrally in the political purchase of the gift. At the durbars attended by Hindu and Muslim elites in eighteenthcentury India, gift exchanges created enduring relationships of mutual obligation between Mughal rulers and their subjects. Ritual prestations to rulers by their subordinates of coins and other precious

\footnotetext{
${ }^{5}$ For broader discussions of the overlap between gift and commodity exchange in 'modernising' societies, see esp. Jonathan Parry and Maurice Bloch (eds), Money and the Morality of Exchange (Cambridge: Cambridge University Press, 1989).
} 
objects, and counter-gifts by rulers of cloaks, turbans and shawls lent physical substance to political allegiance in pre-colonial India. As Bernard Cohn has observed, 'The recipient was incorporated through the medium of the clothing into the body of the donor' ${ }^{6}$ The colonisation (and cannibalisation) of Indian textile production by British merchants under first Company and then Crown rule failed to destroy these associations between gifting, the body and political allegiance in nineteenth-century India. In Chris Bayly's analysis, 'the spirit of the gift... continued to adhere to products that were circulated within a fully developed market system' in Victorian India. ${ }^{7}$

So too in Georgian Britain, ordered systems of gift exchange were central not only to the traditional power wielded by landed aristocrats but also to the new forms of social authority that emerged in the consumer revolution. Dowries and settlements regulated the exchange of women as marriage partners among the elite; systematic gift-giving was likewise conspicuously evident in the clientage networks over which aristocratic patrons presided in both the social and the political sphere. ${ }^{8}$ Rather than detracting from such traditional gift exchanges, the expanding Georgian consumer market lent them new life. As novel techniques of craftsmanship and factory production brought new commodities to the consumer market, elite men and women incorporated fashionable textiles, toys and trinkets into their strategic gifting repertoires. ${ }^{9}$ Imperial conquest further enhanced this process

${ }^{6}$ Bernard S. Cohn, 'Representing Authority in Victorian India', in Eric Hobsbawm and Terence Ranger (eds), The Invention of Tradition (Cambridge: Cambridge University Press, 1983), p. 168. See similarly Gavin R. G. Hambly, 'The Emperor's Clothes: Robing and "Robes of Honour" in Mughal India', in Stewart Gordon (ed.), Robes of Honour: Khil'at in Pre-Colonial and Colonial India (New Delhi: Oxford University Press, 2003), pp. 31-49.

7 C. A. Bayly, 'The Origins of Swadeshi (Home Industry): Cloth and Indian Society, 1 700-1930', in Arjun Appadurai (ed.), The Social Life of Things: Commodities in Cultural Perspective (Cambridge: Cambridge University Press, 1986), pp. 285-321, citation p. 286.

${ }^{8}$ See for example John Habakkuk, Marriage, Debt and the Estates System: English Landownership I650-1950 (Oxford: Clarendon Press, 1994), and Marcia Pointon, Strategies for Showing: Women, Possession and Representation in English Visual Culture I 665I 800 (Oxford: Oxford University Press, 1997), chap. 2.

${ }^{9}$ See esp. Maxine Berg, 'Women's Consumption and the Industrial Classes of Eighteenth-Century England', Journal of Social History, 3o, 2 (Winter 1996), pp. 41 $5^{-}$ 34; Margot Finn, 'Men's Things: Masculine Possession and the Consumer Revolution', Social History, 25, 2 (May 2000), pp. 133-55, and Amanda Vickery, The Gentleman's Daughter: Women's Lives in Georgian England (New Haven: Yale University Press, 1998). The early modern antecedents of the English gift economy, with particular reference to textiles, the body and the self, are explored in Ann Rosiland Jones and 
of evolution, bringing a wealth of new and exotic goods into carefully orchestrated systems of circulation that inculcated habits of deference within the social hierarchy.

The private correspondence and probate records of the AngloIndian governing classes provide a salutary reminder of the extent to which modern consumer relations were imbricated with supposedly pre-modern understandings of exchange. These documents also illuminate in new ways the roles played by collective social identities in shaping modern consumer behaviours. The conceptual and empirical limitations posed by the abstract category of the economic individual have become increasingly evident as our understanding of consumer society has expanded. ${ }^{10}$ Rather than merely contrasting collective social identities to the hedonistic, acquisitive individualism that has hitherto dominated models of Western consumer modernity, however, I wish to locate (indeed, to embed) the possessive individual within the relations of colonial family, kinship and marriage. Linking the history of consumption more closely with the imperial history of the family and its emotional life, I hope to suggest the extent to which the self and the social overlapped in British consumer relations in the Romantic era.

$* * * *$

For men and women of the governing classes who travelled to India in the later eighteenth and early nineteenth centuries, the dual demands of physical and material life rapidly acquired new salience and urgency. Superior diet and accommodation appear to have buffered the governing classes' exposure to mortality relative to enlisted men, but death rates on the subcontinent were forbiddingly high even among the elite. ${ }^{11}$ Exacting an enduring emotional toll from surviving

Peter Stallybrass (eds), Renaissance Clothing and the Materials of Memory (Cambridge: Cambridge University Press, 2000).

${ }^{10}$ Recognition of these limitations has been promoted in particular by gender analysis. For an overview to these issues, see Julia A. Nelson, 'Abstraction, Reality and the Gender of "Economic Man", in James G. Carrier and Daniel Miller (eds), Virtualism: A New Political Economy (Oxford: Berg Press, 1998), pp. 75-94. For an analysis of this problem in Britain, see Margot Finn, The Character of Credit: Personal Debt in English Culture, I740-19I4 (Cambridge: Cambridge University Press, 2003).

${ }^{11}$ Philip D. Curtin, Death by Migration: Europe's Encounters with the Tropical World in the Nineteenth Century (Cambridge: Cambridge University Press, 1989), p. 4. 
kin, these deaths were also administratively taxing. In Britain, family members, neighbours and local creditors were centrally involved in the disposition of decedents' property at probate. Married women in particular played a vital part in probate processes in England: a high proportion of husbands appointed their wives as the sole or joint executrixes of their estates. ${ }^{12}$ The fragmented and diasporic nature of Anglo-Indian social relations, however, precluded the replication of such administrative conventions on the subcontinent. When colonists died far from their natal or marital families, the ability of wives and kin to participate in probate was significantly reduced. ${ }^{13}$ Executors, compelled to grapple not only with excessive mortality rates but also with Anglo-Indians' excessive consumer purchasing, faced an onerous task in attempting to dispose of decedents' material goods. This goal was accomplished most expeditiously by the public sale of personal and household goods at auction. Advertised in the newspapers of Bombay, Calcutta and Madras and attended by all and sundry, these probate auctions underlined not only the fragility of colonists' physical existence but also the instability of their place within the collective memory of the Anglo-Indian community. 'Here people die one day, and are buried the next', Lucretia West commented of Georgian Bombay. 'Their furniture sold the third, and they are forgotten the fourth'. ${ }^{14}$

Tearing the fabric of social life by dispersing deceased AngloIndians' goods to strangers, probate auctions also offered the canny Anglo-Indian consumer a wealth of purchasing possibilities. Here Asian and European consumables of all varieties were available for inspection and acquisition; here too the historian can gain an exceptionally detailed view of the consumer tastes of the British expatriate community. The records of these probate auctions

${ }^{12}$ Nigel Goose and Nesta Evans, 'Wills as an Historical Source', in Tom Arkell, Nesta Evans and Nigel Goose (eds), When Death Do Us Part: Understanding and Interpreting the Probate Records of Early Modern England (Oxford: Leopard's Head Press, 200o), p. 65.

${ }^{13}$ The prevalence of irregular unions between British men and indigenous women in this period further exacerbated this problem, as these mistresses, concubines and wives were often unknown to or not accepted by the government or family members who remained in Britain. See esp. Christopher Hawes, Poor Relations: The Making of an Eurasian Community, I773-1833 (Richmond: Curzon, 1996), and Durba Ghosh, 'Making and Un-Making Loyal Subjects: Pensioning Widows and Educating Orphans in Early Colonial India', Journal of Imperial and Commonwealth History, 31, 1 (January 2003), pp. 1-28.

${ }^{14}$ Cited by E. M. Collingham, Imperial Bodies: The Physical Experience of the Raj, c. I 80o-1947 (Cambridge: Polity, 2001), p. 1. 
repeatedly attest to the triumph of consumer culture in British India, documenting the ownership by individuals of hundreds-indeed thousands - of household and personal goods. The inventory of Mrs Johanna Lee, whose goods were sold at a public auction in Bengal in 1804 , extends over seven pages, with two columns of goods entered per page. The first page alone lists 696 possessions-some of which, like Lee's dinner set, themselves contained multiple items. Comprising fashionable Eastern commodities such as 'an Oval Japanened Tea Tray', 'a China Tea Box' and 'a small Green painted Hookah Screen', the list also suggests Lee's determination to maintain a British identity amidst her 'Oriental' surroundings. Her possessions thus included a pianoforte manufactured by Longman \& Broderick, 'a Black Bust of Shakespeare', ' 16 Prints from Shakespeare in Gold burnished frames', Johnson's Dictionary and ' 15 Squares of Windsor Soap'. ${ }^{15}$

Johanna Lee's inventory was unusual-although not exceptionalin its vast extent, but her possessions were broadly typical in reflecting the cultural hybridity of Anglo-Indian consumer preferences. Indian textiles and garments intermingle with English hunting boots and French silk waistcoats in Anglo-Indian probate records; Greek lexicons, Latin grammars and Samuel Johnson's Dictionary vie for the potential purchaser's attention alongside Persian poetry, Sanskrit legal texts and the Bhagvat Gita. The sale inventory of Captain Charles Hay's effects, filed in Calcutta on 6 March 1780, illustrates this prevailing characteristic of Anglo-Indian consumer culture. Extending over more than eight pages, the inventory includes a European cloak, 'a pair of Pigdamies', eight pairs of European shoes, four pairs of 'Hindustan slippers', one piece of European muslin, two pieces of Madras muslin, a 'Europe hunting saddle', and a 'Country made' (that is, Indian) saddle, a European phaeton and an Indian phaeton, as well as boasting a crystal mouthpiece set with diamonds and emeraldsthe latter, presumably, a component of Hay's hookah. In matters of the mind as in his bodily wants, Hay's consumer sensibilities reflected his immersion in a material world of goods that was marked by crosscultural currents of exchange. His library included 'a large Persian dictionary' as well as works by Congreve, Dryden, Fielding, Gay, Pope, Shakespeare and Samuel Johnson's Dictionary. ${ }^{16}$ These hybrid

${ }^{15}$ Oriental and India Office Collection, British Library (henceforth OIOG), L/AG/34/27/30, Bengal Inventories, inventory $3^{6 .}$

16 OIOC, L/AG/34/27/1, Bengal Inventories, inventory 10 . Such social and cultural hybridity was pervasive in this period, as Swati Chattopadhyay argues in 'Blurring 
consumer behaviours reflected utilitarian needs as well as individual purchasing preferences. Collingham and other historians have drawn attention to the willingness of late eighteenth- and early nineteenthcentury Anglo-Indian men-in sharp contrast to their Victorian successors-to internalise aspects of Indian social and cultural life. By ingesting Indian foodstuffs and cookery, cohabiting with Indian wives and concubines and adopting Indian practices of personal hygiene, men of the Anglo-Indian governing classes acted to preserve their physical and emotional health while forging valuable political and economic links to indigenous Hindu and Muslim elites. ${ }^{17}$

\section{$* * * *$}

For the acquisitive individual, probate auctions offered an expedient means of satisfying egocentric consumer desires, but for the families of deceased Anglo-Indians the sales were often emotionally and administratively fraught. The sudden death of kin, whether in India itself or on the ships that carried colonists to and from the subcontinent, repeatedly threatened to compromise the orderly transfer of personal property within British families. Like the goods of Anglo-Indians who died within the three Presidencies, the personal effects of colonists who died at sea were liable to public auction, a practice that threatened to deprive relatives of precious relics and mementos of the deceased. In 1 805, John Elliot-a younger son of the soon-to-be Governor General of India, Lord Minto-journeyed to India as a Writer in the Company service, and was appointed auctioneer to dispose of the goods of a cadet who had died after the ship set sail. 'I can assure you I performed the office famously', Elliot wrote proudly to his father, noting virtuously that he himself had resisted the temptation to purchase any of the goods other than a book and some quires of fine English writing paper. ${ }^{18}$ When his own brother, William, died of galloping consumption en route home to Britain on board the Fox six years later, however, John Elliot came to understand at first hand the

Boundaries: The Limits of "White Town" in Colonial Calcutta', Journal of the Society of Architectural Historians, 59, 2 (2000), pp. 154-79.

${ }^{17}$ See esp. Collingham, Imperial Bodies, pp. 13-49; William Dalrymple, White Mughals: Love and Betrayal in Eighteenth-Century India (London: HarperCollins, 2002); and Hawes, Poor Relations.

${ }^{18}$ John Elliot to Lord Minto, 28 September 1805 , National Library of Scotland (henceforth NLS), Minto Papers, MS 11094 , fol. 74 verso. 
emotional turmoil that was unleashed within Anglo-Indian families by the public sale of their loved ones' private possessions. Before William set sail in 1811, his brother had secured a few locks of his hair for distribution among the family in the event of William's death, but as John Elliot observed anxiously in a letter home to his mother, the hair was 'so very short, I am afraid no use can be made of it further than setting a small quantity in rings'. The paucity of William's hair placed a premium on the family's retention of his material effects. Before the Fox left Calcutta, John Elliot begged the ship's captain 'as a favour' to prevent William's goods from being sold 'to the highest bidder' in the event of his death on shipboard. 'He promised me he would as far as was in his power prevent his things from being touched but that it was necessary a few of his clothes should be sold as there is an order which obliges a Captain to sell them', Elliot reported to Lady Minto. ${ }^{19}$

In these circumstances, the care and solicitude of servants, ship's officers and fellow passengers proved vital, for it was individuals such as these who served as human links in the chain of communication that united surviving relatives in Britain and India through the exchange of personal memories-emotional exchanges that were, in turn, mediated by the transfer of personal possessions. William Elliot was attended on his final journey on the Fox by a servant named Goldsmith, who upon his disembarkation in England travelled north to the Minto family estate in Scotland. Here Goldsmith delivered William's remaining goods to Lady Minto and recounted the details of William's last illness and death as well as the activities of the family members who had remained in India. Having fulfilled these duties, Goldsmith was entrusted with a selection of William's possessionswatches, seals, sleeve buttons and the like-to distribute (together

${ }^{19}$ John Elliot to Lady Minto, [October 1811], NLS, Minto Papers, MS 11095 , fol. 193. The use of rings or broaches to circulate the hair of distant or departed kin between metropole and colony was a commonplace in Anglo-Indian material and emotional life. When Lady Anne Russell, the mother of Charles and Henry, dispatched her third son (Frank) to join his father and brothers in India in 1808 , she gave him three broaches for circulation that contained 'the hair of each individual of our family now in England'. She also promised to send her sons rings made with the hair of Colonel Kirkpatrick, who until his demise had been their patron and superior in Hyderabad. Anne Russell to Charles Russell, 25 February 1808, Bodleian, MS Eng. lett. c.154, fol. 120 . On memorial objects crafted with hair, see A. L. Luthi, Sentimental Jewellery: Antique Jewels of Love and Sorrow (Princes Risborough: Shire Publications, $1998)$. 
with news of the family at Minto) when he returned to Calcutta in $1812 .^{20}$

A ring delivered by Goldsmith and presented to John Elliot's wife, Amelia, illustrates the complex strands of remembrance that were woven into the material objects that circulated within and between Anglo-Indian families in this manner. Originally given to William Elliot by his brother George before the Fox set sail, the ring constituted a memorial object even before William's death, for it contained a strand of hair taken from Jane Russell-Amelia Elliot's sister, who had died in Madras within weeks of her marriage to the young Henry Russell in 1808 . Sailing to India with a third sister and their parents in 1805, Jane and Amelia had befriended the young John Elliot, forming an adoptive family on shipboard into which he would later choose to marry. The ring crafted with Jane's hair was entangled with a web of family relations that stretched over time and space. Compact, easily portable and designed to be worn on the body, it offered an ideal material mechanism for the circulation of family memories and identities among kin who were often, given the demands of colonial family life, personally unknown to each other. Gifted in India to the dying William Elliot by his brother George and adorned with the hair of his sister-in-law's deceased sister, the ring circulated through the family circle at Minto before returning to Government House in Calcutta, where Lord Minto shared his official residence with John Elliot, Amelia Elliot and Amelia's surviving sister, Elizabeth. ${ }^{21}$ Having distributed William's returned effects among the family members resident in Bengal, John Elliot promptly initiated a further cycle of commemorative gifting, sending four lockets containing strands of William's hair to Scotland in June $1812 .{ }^{22}$

The ring containing a strand of Jane Russell's hair, which George Elliot had given to his dying brother William in 1811 , was only one among a host of relics that commemorated Jane's life and death in India. Born in England to a Scottish mother and a father of mixed British and Portuguese descent, Jane Casamaijor had been the reigning belle of Anglo-Indian society in Madras when she married Henry Russell at the age of nineteen in 1808 . Henry, as his private

${ }^{20}$ John Elliot to Lady Minto, 2 April 181 2, NLS, Minto Papers, MS 11095 , fols 228 verso-229.

${ }^{21}$ Ibid.

${ }^{22}$ John Elliot to Lady Minto, 22 June 1812, NLS, Minto Papers, MS 11095 , fol. 243 verso. 
correspondence reveals in excruciating detail, was devastated by his young wife's death from a violent gastric disorder only a few weeks after their wedding. Separated from his brother Charles (who was posted in Hyderabad), from his father Sir Henry (who was the senior judge of the Supreme Court in Calcutta) and from his mother Anne (who had been forced by ill health to return with her youngest children to England), the bereaved Henry Russell turned to his wife's family for emotional support. 'The Parents of my Angel are like Parents to me.... and, in their Family, I have every Consolation, every Support that Madras can possibly afford me', Henry wrote to his brother in the first hours of his bereavement. 'In that, I have a Comfort which, in this Country, this cruel, cruel Country, is denied to almost everybody'.23 Remaining with his in-laws in the following weeks, Henry could face the prospect of returning to his marital home only by contemplating the sale and removal of the material goods that would remind him so insistently there of his loss. In January 1809 , he informed Charles of his decision to 'sell off all my Plate, Furniture, and Equippage'. 'The very sight of the House in which I lived so happily with my Jane, will always be painful to me; and Society and Splendour have lost to me every Charm that they possessed', he wrote morosely to his brother. ${ }^{24}$

By February, Henry had commissioned Charles to negotiate with potential purchasers of his household goods, carriage, plate and jewels. Even a partial list of Henry's possessions conveys a sense of the intensity of the hedonistic Anglo-Indian elite's immersion in fashionable consumer culture in this period. In 1809 , Henry was bereft of permanent employment and had yet to amass his fortune. But his myriad household goods none the less included two Egyptian couches, a chintz-covered Ottoman that measured twelve feet in length, a dozen black varnished chairs with a red Etruscan border, a secretary and bookcase with Egyptian bronze figures, 'a pair of the newest fashioned Sofa Tables on Pillar Legs inlaid with Brass and fitted up with Brass Ornaments to match the Secretary', a 'green silk folding Screen of four Folds', a set of claw-footed dining tables to seat twenty-six persons and

${ }^{23}$ Henry Russell to Charles Russell, 29 December 1808, Bodleian, MS Eng. lett. c. ${ }_{15} 6$, fols. 107-108. He reiterated these sentiments constantly. See for example Henry Russell to Mrs Casamaijor, [18o9], ibid., fols 183-183 verso.

${ }^{24}$ Henry Russell to Charles Russell, 1 January 1809, Bodleian, MS Eng. lett.

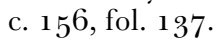


mahogany furniture that included two dozen dinner chairs, a chest of drawers and a music stand. ${ }^{25}$

Having disposed of these painful possessions, Henry was poised to invest in new objects with which he could commemorate (and control) the memory of his wife. Like Lord Minto's family when faced with William Elliot's death, the Russells and the Casamaijors responded to Jane's demise by circulating a variety of possessions associated with her physical person among surviving kin in Britain and India. Because Jane and Henry Russell's marriage had endured for only a few scant weeks, these gift exchanges functioned as constitutive-rather than as purely commemorative-social acts. By exchanging material (often corporeal) objects between the two kin groups over the next several years, the Russells and the Casamaijors forged an enduring union between the two families - a union that would ordinarily have been accomplished through the birth of children to Henry and Jane. Henry Russell was an especially keen observer of such familial exchanges, and was himself highly skilled in the complex art and craft of strategic gift-giving. His deployment of Jane's memory operated simultaneously on three fronts, serving at once as a means of emotional expression, as a mechanism of family formation ideally suited to the exigencies of empire and as a political tactic calculated to yield concrete economic gains.

Jane's family in Madras formed the initial focus of his attention, which radiated over time across the subcontinent to his own kin as well as to members of both families in Britain. Even as he negotiated through his brother Charles for the sale of his marital goods-and thus sought to break the chain of painful associations embodied in these material possessions-Henry laboured to reinforce his links with Jane's parents by binding them to him through emotionally-laden exchanges of both goods and sentiments. In March 1809 , three months after Jane's demise, Henry presented his mother-in-law with 'a small full length drawing of myself' and composed 'a short address' to Mrs Casamaijor to accompany this present. 'To her who is bound to me by a Tie, which, though removed, can never be dissolved; and to whom it is my Pride to love, and consider, as my Mother, I offer this Shadow of myself', Henry wrote with feeling on the back of the drawing. ${ }^{26}$ James

${ }^{25}$ Henry Russell to Charles Russell, 26 February 1809, Bodleian, MS Eng. lett. c. 156 , fol. 154 verso.

${ }_{26}^{6}$ Henry Russell to Charles Russell, 22 March 1809, Bodleian, MS Eng. lett. c. 156 , fols. 191 verso- 192 . 
Casamaijor, Jane's father, was likewise the recipient of a stream of letters and gifts designed to reinforce Henry's identity as his son-inlaw. In 1810 , Henry left Madras to take up a diplomatic appointment in Poona, from whence he instructed his Indian servant to send James Casamaijor a gift freighted with bodily significance. 'I have desired him to give my large Chair, in which I always used to write, to you; and I hope that you will put it in your own Room, and keep it there in Remembrance of me', Henry wrote to Casamaijor in August. 'Our poor Darling used it during the Commencement of her Illness, so that it has a double Claim on your Regard'. ${ }^{27}$

Incorporating members of his own family who had never met Jane into the conjoint Casamaijor-Russell clan preoccupied Henry for years after his wife's death, engaging him in constant correspondence and precipitating a succession of gift and counter-gift transactions among his widening Anglo-Indian kin network. In Britain, to which they had both retreated to preserve their health, Henry's mother and motherin-law worked tirelessly to incorporate Jane into the circle of sisters over which she would have presided had she survived and returned from India with her husband. 'My Sister mentions, in a Letter I had from her the other Day, that Mrs Casamaijor had given them, all four, Broaches with poor Jane's and my Hair, which of course they prize very dearly', Henry wrote to his father-in-law in 1811 . 'The Happiness of social Life depends much more upon [such] Trifles than people generally imagine', he concluded. ${ }^{28}$ Consolidated further by a succession of gifted portraits and miniatures that circulated between and within Britain and India, these transactions underpinned the creation of a family unit that existed at once in the realm of sentiment and in the social world. Lady Anne Russell, anxious to encompass not only Jane's memory but also her surviving sisters within the Russell circle, invited Jane's younger siblings, Henrietta and Louisa, to spend their school holidays with her own daughters. ${ }^{29}$ By 1812 , Henry could

${ }^{27}$ Henry Russell to James Casamaijor, 2 August 1810 , Bodleian, MS Eng. lett. d. 162 , fol. 65 verso. Somewhat to Henry's embarrassment, his servant dispatched the wrong chair to Casamaijor, and the intended gift was claimed instead by Henry's former office-mate, Parker. 'I shall send him a Seal that I have always worn, as a Keepsake, for which Purpose he seems desirous to keep the Chair', he explained. 'The Chair must be yours.' Henry Russell to James Casamaijor, 31 August 1810, ibid., fols. $72-72$ verso.

${ }^{28}$ Henry Russell to James Casamaijor, 13 July 181, Bodleian, MS Eng. lett. d. 163, fol. 14 verso- 15 .

${ }^{29}$ Henry Russell to James Casamaijor, 20 June 1810, Bodleian, MS Eng. lett. d. 162 , fol. 46 . 
report with satisfaction to Casamaijor that 'all the Girls consider themselves as Family, and.... I look upon the close Connexion between the two Families as one of the most copious Sources of the Happiness that awaits me on my Return to England'. ${ }^{30}$ Now ensconced in Hyderabad as the British government's chief diplomat, Henry was determined to celebrate and display the enduring union of his two families on the walls of the Hyderabad Residency. He arranged to have his father's portrait painted in Calcutta by the celebrated artist George Chinnery, requested that his mother and two eldest sisters sit for oil portraits in England and commissioned his mother-in-law to obtain 'a Portrait of herself in Oils, and Likenesses of dear Harriet and Louisa, like those of my own two Sisters'. ${ }^{31}$

Representations of Jane herself figured prominently in this ongoing project of collective familial memorialisation. In 1810 , Henry commissioned the fashionable London sculptor John Bacon to produce a large marble monument toJane, depicting 'the Situation in which our beloved actually was at the Moment of her Departure, including her Figure, Mrs Casamaijor's, Elizabeth's, Amelias [sic], and my own'. ${ }^{32}$ The completion of this giant relic was lovingly superintended by his mother and mother-in-law in London, but the monument itself was lost, together with hundreds of passengers and crew, when the Elizabeth sank off the coast of France en route to India in 1811 . Henry promptly re-commissioned Bacon, and a second monument toJane sailed on the Bridgewater in 1813 , arriving safely in Madras, where James Casamaijor oversaw its installation in the parish church. More modest in its dimensions than this monument, but no less saturated with familial emotion, was the miniature of Jane painted by Chinnery, of which her father commissioned a copy for Henry in 1813 . 'Though I wish to have a Copy of the Work, I shall receive it with a trembling Hand, and shall be glad when the first Sight of it is over', Henry confided to Casamaijor. 'I have always thought that Pictures and memorials of departed friends occasion more Pain than Satisfaction; but young People often go out

${ }^{30}$ Henry Russell to James Casamaijor, 3 February 1812, Bodleian, MS Eng. lett. d. 163 , fol. 87 verso.

31 Henry Russell to James Casamaijor, ibid., 13 February 181 , fols. 89 verso-9o. For the social and representational significance of such portraits, see Beth Fowkes Tobin, Picturing Imperial Power: Colonial Subjects in Eighteenth-Century British Painting (Durham, NC: Duke University Press, 1999), pp. 110-38.

${ }^{32}$ Henry Russell to James Casamaijor, 26 February 1819 , Bodleian, MS Eng. lett. d. 164, fol. 122. For Bacon's imperial statuary, see Barbara Groseclose, 'Imag(in)ing Indians', Art History, 13, 4 (December 1990), pp. 488-515 , esp. pp. 488, 507-10. 
of their Way in Search of Subjects of Distress, and it requires much Time and long Experience to make us careful of our Nerves, and desirous of avoiding unnecessary Agitation'. ${ }^{33}$ The copied miniature was circulated from Madras to Henry in Hyderabad via Calcutta, a convoluted journey that allowed Sir Henry Russell to pronounce favourably-through the mediation of this material object-upon the person of his late daughter-in-law. Never having met Jane, Sir Henry was unable to comment on the miniature's likeness, but reported that those who had known her were fully satisfied. 'I, believing it, lament more and more your Loss and mine: What I see confirms all I have heard', he reported to his son. 'This Portrait will I hope remain forever in my Family'. ${ }^{4}$

Sir Henry's professed sense of loss and his willingness to include his son's deceased wife among his kin marked a dramatic reversal of his sentiments, for Henry Russell had married Jane Casamaijor in 1808 without his parents' knowledge or approval. Lacking a substantial dowry, Jane was an unsuitable match for Sir Henry's eldest son and heir, posing an obstacle to the Russells' goal of retiring to England as leisured landed gentry. In autumn 1808, Sir Henry-who had risen to eminence from a modest background through the Law and two strategic marriages-had been alarmed by what he learned of the Casamaijors' lineage. ${ }^{35}$ Jane's mixed ancestry was anathema to her father-in-law, who was horrified to find that she was (on her father's side) the great-granddaughter of a Malay and (on her mother's side) was related to a gaggle of thrusting Scots. Writing in anguish to his son Charles a month after the wedding, Sir Henry described the letter of remonstrance he had sent to his eldest child. 'I represented to him how disagreeable to me it was that the blood of my descendants should be contaminated by one streak of black', he reported, 'besides too I

${ }^{33}$ Henry Russell to James Casamaijor, 12 August 1813, Bodleian, MS Eng. lett. d. 164 , fols $64-64$ verso.

${ }^{34}$ Henry Russell to James Casamaijor, February [1813], Bodleian, MS Eng. lett. d. 164 , fol. 74. The social economy of miniatures in elite British society is detailed by Marcia Pointon, “Surrounded with Brilliants": Miniature Portraits in EighteenthCentury England', Art Bulletin, 83, 1 (March 2001), pp. 48-71; their particular utility in colonial circuits of emotional exchange is noted by Patrick Conner, George Chinnery I774-I 852: Artist of India and the China Coast (Woodbridge: Antique Collectors' Club, 1993), pp. 58-9.

${ }_{35}$ For Sir Henry's background see Lady Caroline Russell, Swallowfield and Its Owners (London: Longman \& Co, 1901), pp. 252-3. 
disliked a connexion with the Campbells, which would introduce him to such a vile set of aunts'. ${ }^{36}$

Given Sir Henry's hostility to the match and the fleeting duration of the marriage itself, the longevity and intensity of the CasamaijorRussell family alliance are at first glance surprising. For although Henry Russell was to take a second wife while still in India-with whom he fell deeply in love and by whom he had six children who survived to adulthood-his close connections with the Casamaijors endured into the Victorian era. The constant traffic of gifts, letters, mementos, portraits and visits precipitated first by Henry and Jane's marriage and then by Jane's death had inculcated habits of sociability that survived the full return of both families to England and the gradual erosion of their links to India. Swallowfield, the Berkshire estate that was home to Henry and his second wife upon their return to England, was located at a convenient distance from the widowed Mrs Casamaijor's residence in Reading, and three generations of the two families were to exchange neighbourly visits, correspondence, garden produce and gifted consumer goods from these twin bases for decades. Mrs Casamaijor's death in 1837 reminded Henry Russell forcibly of the strength and significance of the emotional bonds that had been forged thirty years earlier in Madras. As he lamented to Charles, 'She was to me what no other human being was, or ever could be, and, at my age, her loss was irreparable'. ${ }^{37}$

The gift relations established and maintained between the Russell and Casamaijor families provided an ongoing source of emotional satisfaction, but these transactions represented much more than a sentimental exercise in colonial happy families. For the quotidian exchange of domestic goods and social niceties between kin laid the groundwork upon which Anglo-Indian political and economic ambitions rested. Gift transactions loomed large at every level of politics in British India-as they did in the British metropole itself. Indian subjects schooled in the politics of exchange by Mughal durbars courted favour with their new British overlords by presenting them with a cascade of luxurious textiles, while Anglo Indians accustomed to the demands of the British patronage system sought to curry interest in metropolitan corridors of power by sending exotic Oriental

${ }^{36}$ Sir Henry Russell to Charles Russell, 20 November 1808, Bodleian, MS Eng. lett. c. 152 , fol. $9^{2}$ verso.

${ }^{37}$ Henry Russell to Charles Russell, 25 February 1837, Bodleian, MS Eng. lett. c. 162 , fol. 104 . 
presents home to influential friends and family members. ${ }^{38}$ Within the expatriate community itself, gifts of Eastern and Western goods were the common coin of Anglo-Indian friendship and patronage: Charles Russell's gift of a handsome Greek lexicon to his fellow officer, James Russell, was only one among a multitude of such fraternal exchanges recorded in the Russell family correspondence.

Both natal and marital families figured centrally in the politics of Anglo-Indian gifting. Kin networks were the key recipients of gifted largesse, but they also provided the essential mechanisms by which these strategic exchanges were regulated. Henry Russell's relentless reinforcement of his link with the Casamaijor family after Jane's death reflected his understanding of the power relations mobilised through family connections by gift-giving in the political sphere. For although James Casamaijor was rendered racially suspect to Henry's father by his possession of a Malay grandmother, he was none the less a member of the Madras Council, and in this capacity wielded substantial power and influence. To Henry, Casamaijor was, as his father-in-law, both the most appropriate recipient of his anguished letters in the aftermath of Jane's untimely death and the natural conduit through which Henry's strategic gifts should pass to his superiors in the government. In a letter sent from Poona in 1810 , Henry inquired anxiously about his current status in the estimation of Sir George Barlow-Governor of the Madras Presidency-and expressed his desire to exploit 'any Opportunity' to evince his esteem for the Governor. He matched this query with a request that Casamaijor serve as his intermediary in a strategic gift exchange with Barlow's wife. 'I trouble you, by to day's Post, with a Packet for Lady Barlow, containing a Piece of printed Linen, which she commissioned some Time ago', he informed Casamaijor. 'By tomorrow's Post I shall trouble you with another Parcel of the same kind; and shall be much obliged to you to send them to her Ladyship. ${ }^{39}$

${ }^{38}$ Bayly, 'Origins of Swadeshi', pp. 286-302 provides a sensitive synopsis of precolonial and colonial Indian gifting, focusing on the exchange of cloth; P. J. Marshall offers a detailed overview from the perspective of eighteenth-century Company servants in East Indian Fortunes: The British in Bengal in the Eighteenth Century (Oxford: Clarendon Press, 1976), pp. $15^{8-79}$.

${ }^{39}$ Henry Russell to James Casamaijor, 28 April 1810 , Bodleian, MS Eng. lett. d. 162 , fols. 14-15. It was Sir George Barlow who convinced the Madras authorities to agree that Jane's tomb could be placed within the church itself rather than relegated to the churchyard. 'Nothing could be kinder than his Conduct; and I never will forget it as long as I live', Henry wrote. 'On many a stormy Night I have recollected, with 
The courtship and marriage of Amelia Casamaijor, Jane's sister, and John Elliot, Lord Minto's son, added a further dimension to Henry's strategic gifting by connecting the Russell family through the Casamaijors to the chief font of British government patronage on the subcontinent. The Casamaijors had provided John Elliot with a surrogate family circle on shipboard when he first sailed to India in 1805 , and both Elliot and his father ignored rank and precedence to favour the Casamaijors over the Barlows when political developments compelled them to travel to Madras in 1809. Henry Russell was quick to recognise (and seize upon) the opportunities afforded by this 'Intimacy with the Casamaijors', although he professed an aversion to seeking political advancement through the influence of female kin. 'This Connexion... is likely to bring me a good deal [into contact] with Lord Minto and his Family; and can scarcely fail to have the Effect of increasing the Interest which Lord Minto feels about me; but you may do me the Credit to believe, that I will allow it to work these Effects silently, without currying favour with any of the Members of his Family, or preferring Requests under the Influence of the Petticoat', Henry wrote to his brother Charles in September. 'If Elliot and I should become intimate, it is possible that he will take occasional Opportunities of mentioning me to his Father ... and if Lord Minto is so desirous as I think he is, to gratify Mrs Casamaijor, and to make her some Return for the invariable Kindness she and $\mathrm{Mr} \mathrm{G}$ have shewn his Sons, he will soon discover that he cannot do so in any Way which would be so acceptable to her, as by providing for me' ${ }^{40}$ Henry's overweening egotism-his sense of himself as an individual with specific needs and entitlements-is conspicuously evident in his correspondence, but the mechanisms through which his needs were channelled and the goals to which they were directed reflected his immersion in collective networks of extended kin. In this social and political context, gifts and commissions of consumer luxuries offered an effective mechanism for manifesting loyalty to patrons and clients by linking members of the three families in India to their kin at home through extended chains of mutual obligation. 'Lord Minto has asked

Tears in my Eyes, that it is to him we are indebted for our sweet Love's Remains being deposited under Shelter.' Henry Russell to James Casamaijor, 29 July 1811 , Bodleian, MS Eng. lett. d. 163 , fol. 19 .

${ }^{40}$ Henry Russell to Charles Russell, 19 September 1809 , Bodleian, MS Eng. lett. c. $\mathbf{1 5} 6$, fols. 266-266 verso. For the key role of elite women in English patronage networks, see esp. Elaine Chalus, 'Elite Women, Social Politics and the Political World of Late Eighteenth-Century England', Historical Journal, 43, 3 (2000), pp. 669-98. 
Mrs Casamaijor, to ask me, to ask you, to send him some Opals for Lady Minto', Henry wrote to Charles a few days later. 'Proctor, who is sitting by me, says that if you send this Opal to the G.G. [Governor General] it will be reasonable to hope all'. ${ }^{41}$

The 'all' for which Henry Russell hoped and schemed so fervently was a diplomatic posting to the British Residency at Hyderabad, an appointment that lay in Lord Minto's gift as Governor General. Described by Henry as 'the Summit of my Ambition in India', the appointment promised that most elusive desideratum of Anglo-Indian life, 'a handsome Fortune within a reasonable Period'. Woven into a broader fabric of exchanges that featured gems, textiles, chairs, books, portraits and memorial objects, Minto's decision to confer the Residency upon his daughter-in-law's brother-in-law in 1810 naturally figured in Henry's interpretation as yet one more gift exchange among marital kin. 'Of this great and unexpected Success, I feel that I owe a large Portion to my Connexion with you', he wrote to Casamaijor on learning of his appointment. 'And I am glad that it is so; for anything that comes to me through anybody connected with her who was my Wife, comes to me with double Satisfaction'. ${ }^{42}$ Eschewing the nakedly monetary calculations of the cash nexus, Henry expressed his gratitude in the language of the gift. In this ceremonial discourse, value was determined as much by the manner in which an exchange was conducted as by its mere utility. As Henry noted approvingly of the letter in which Minto announced his appointment as Resident, it was 'all Delicacy and Goodness; and, not content with the Value alone of the Gift he conferred, he chose that Way of conferring it which would have rendered it, if possible, a Source of greater Gratification than it was in itself' ${ }^{43}$

$* * * *$

The gift economy that animated Anglo-Indian society and politics drew essential sustenance from pre-colonial modes of production and exchange, circulating among the British colonial elite goods such as

${ }^{41}$ Henry Russell to Charles Russell, 28 September 18o9, Bodleian, MS Eng. lett. c. 156 , fol. 268 .

${ }^{42}$ Henry Russell to James Casamaijor, 13 May 1810 , Bodleian, MS Eng. lett. d. 162 , fols. 20 verso-2 1 .

${ }^{43}$ Ibid., fols. 21 verso-22. 
indigenous textiles that were to resist full commodification on the subcontinent throughout the nineteenth century. Within the ruling classes, blood-relations and in-laws alike participated actively in this venerable system of exchange. Relatives commissioned and gifted elaborately embroidered and bejewelled Indian costumes for newborn kin to mark their inclusion in Anglo-Indian family networks; richly dyed and finely woven Indian shawls likewise passed at frequent intervals from sons in India to mothers in Britain, and thence into the hands of influential aristocratic patrons. ${ }^{44}$ But the history of Anglo-Indian gifts was also enriched and expanded by novel Western consumer goods. To be sure, contemporary stereotypes emphasised the fundamental incompatibility of gift exchange and modern commodity culture. The much-maligned nabob figured in the Georgian imagination as a hedonistic consumer whose compulsive selffashioning defied the mutualistic goals and norms of gift exchange: the nabob was a quintessentially modern individual, untrammelled by social obligations and cultural constraints when he entered into the market for fashionable goods, a marriage partner or a place in Parliament. ${ }^{45}$ Probate inventories provide abundant evidence that Anglo-Indian men and women were indeed rapacious consumers of European goods, and the private correspondence of AngloIndian families-the very letters that provide such rich testimony to the Anglo-Indian gift economy-also speak eloquently on this point. Desire and longing for fashionable European consumables permeate the letters sent by Anglo-Indians home to their families in Britain, alerting their readers to the insistent, individualistic passion for possessions that marked contemporaries' engagement with material culture. These sources attest to the coexistence of gift- and commodity-orientated exchange within the Anglo-Indian family, and also illustrate the ways in which Western consumer goods came to

${ }^{44}$ When Amelia Elliot prepared for her first confinement in 1810 , Henry Russell sought 'a very rich Suit of Marhattah Cloaths for the Child' and commissioned his brother Charles to obtain a topi 'of the smallest Size, and as rich as it can be made'. Henry Russell to Charles Russell, 13 September 1810 , Bodleian, MS Eng. lett. d. 151, fol. 253. 'I have got the beautiful black shawls sent to me by your invaluable and ever to be lamented Friend Col. Kirkpatrick.... they are quite the rage now in London, and nothing is sought after but black or scarlet shawls-they are however so scarce, that those sent to me really prove invaluable', Lady Anne Russell reported to her son Charles on 29 August 1806. Bodleian, MS Eng. lett. c. 154, fol. 102 verso.

${ }^{45}$ For the nabob, see Collingham, Imperial Bodies, pp. 13-49, and Thomas Spear, The Nabobs: A Study in the Social Life of the English in Eighteenth Century India (2nd edn., London: Curzon, 1980). 
be re-inscribed as 'modern gifts' in colonial India. This process of re-inscription was itself mediated by modern consumer ideologies, most notably by the vogue that Romantic fiction, poetry and sentiment enjoyed among the British governing elite.

The Elliot and Russell family papers are replete with letters from expatriate menfolk begging for gifts of consumer goods from home. Indolence and overindulgence on shipboard ensured that John Elliot acquired the nabob's stereotypical body-type even before he reached Madras in 1806, and his first urgent pleas to family members for English items of apparel were thus dated from the Cape. 'I am got so monstrous fat that all my clothes are too small breeches particularly, especially about the behind, \& I compare myself to nothing but a large pudding in a small pudding bag', he wrote to his father from Cape Town. 'I also stand in great need of boots'. ${ }^{46}$ Cost was a key consideration in pleas for goods from Britain, as European consumables had commanded twice their British market price in India since at least the $175^{\mathrm{Os}}{ }^{47}$ But considerations of consumer price were overshadowed in family letters by consumer desires, social strategies and political calculations. Fashion was a key determinant of consumer appeal for expatriates, ever anxious to underline their continued links to the metropole. 'Have you brought me nothing from Europe? No fashionable articles of dress?', was Henry Russell's querulous demand when his brother Charles first arrived on the subcontinent in 1802 . Henry's appeals to shared family sentiment and his tactical discussions of patronage elided easily with his demand for European consumer goods, for familial exchanges existed at the interface between emotional, financial and political economies of obligation in Georgain culture. 'Refer to your own heart for a knowledge of the feelings which agitated my breast during the whole of the day', Henry wrote effusively upon reading Charles's first letter from Calcutta. 'I look with much anxiety to the receipt of another Letter from you which must contain such interesting accounts of all so truly dear to us in England', he continued. 'Did you all receive the little presents I sent you?' These inquiries after his younger siblings gave way seamlessly to requests for information about the senior kin who occupied the apex of the Russells' patronage network in England. 'Did Lady Aylmer get the fans?', Henry asked anxiously. 'By the time I arrive in Calcutta

${ }^{46}$ John Elliot to Lord Minto, February 1806 , NLS, MS 11 o94, fols 89-89 verso.

47 The high cost of genteel English goods in eighteenth-century India is noted by Marshall, East Indian Fortunes, p. 159. 
I shall have prepared a present for the Duchess [of Dorset] from the productions of this part of India-you know there is nothing like applying directly to the touch', he concluded knowingly. ${ }^{48}$

Gifts that required family members to demonstrate their continued devotion to distant kin while allowing expatriates to recreate British styles of life were at a particular premium in India. For John Elliot the accoutrements of a hunting man were prime objects of consumer desire. His letters home are punctuated with requests, pleas and demands for saddles, bridles, whips and most of all purebred hunting hounds. Having arranged to send his mother a consignment of Chinese luxury goods obtained by his brother George in April 1 8o8, John Elliot left Lady Minto in no doubt as to his expectations of an appropriate counter-gift from Britain. 'In return for these fine presents, if you don't send me some hounds... I will cut your acquaintance', he threatened ironically. ${ }^{49}$ A year later, he wrote to thank her for sending seven hounds from Scotland, albeit one had died and another fallen overboard on the passage out. Now the proud owner of 'a very respectable pack' that comprised twenty-seven 'thorough bred' hounds-'quite enough for any Jackal'-Elliot begged Lady Minto to ensure 'a regular supply to keep us going', and underlined the likely consequences if his mother failed in this charge. 'I am certain that if I did not take exercise I should soon be a living lump of suet or a dead corpse', he concluded ${ }^{50}$ His father's letters home reinforced these pleas. 'The best present you can send him is a couple of hounds now \& then, for it is impossible to keep up a kennel from the market in India', he explained. ${ }^{51}$

The Russell and Elliot sons' insatiable desire for gifted European commodities-including the latest English fashions and hunting dogs wholly unsuited to the Indian climate-fits neatly within the stereotypical behaviour of the nabob, obsessed with the demands of his body to the detriment of his mind. A wealth of quantitative and qualitative evidence on expatriate libraries, however, counters this facile interpretation of Anglo-Indian consumer tastes. Books were highly desirable commodities both on the Anglo-Indian market and in familial systems of gift exchange. On finally obtaining his

${ }^{48}$ Henry Russell to Charles Russell, 21 February 1802, Bodleian, MS Eng. lett. c. 155 , fols $1-2$.

${ }_{49}$ John Elliot to Lady Minto, 7 April 1808, NLS, MS 11094 , fol. 143.

50 John Elliot to Lady Minto, 21 April 1809 , NLS, MS 11094 , fol. 168.

51 Lord Minto to Lady Minto, 8 February 1809 , NLS, MS 11064 , fol. 15 verso. 
much-coveted posting to Hyderabad as Resident, Henry Russell willingly agreed to purchase his predecessor's library for a thousand pounds, an exchange he justified in terms that mixed monetary and affective calculations. ${ }^{52}$ His passion for books was shared by many of his contemporaries. Among the probate inventories filed in Bengal in 1812, that of the Reverend D. Brown included 1,329 volumes of books and 23 volumes of pamphlets, while the inventory of P. Speke, Esq., comprised a library of 3,031 volumes, exclusive of 1,125 pamphlets. ${ }^{53}$ Nor was book-buying in India confined to a small elite. The probate records of army captains, lieutenants and surgeons burst with popular histories, travel narratives, classical texts, poetry and the latest works of fiction. The Bible, the Iliad and Shakespeare's plays were staple items in Anglo-Indian libraries great and small, but probate records suggest that many members of the expatriate community indulged distinctive-and often distinctively modernliterary consumer tastes while in India. Lord Minto, who thanked his wife for sending him Madame de Staël's latest novel in 1808, was hardly alone in cultivating his taste for Enlightenment and Romantic writing on the subcontinent. ${ }^{54}$

Philosophically-inspired Enlightenment history enjoyed great vogue among British readers in this period, generating a vibrant popular market that clearly extended from London and its provinces to Bombay, Calcutta, Madras and their hinterlands. Like the books owned by many of his Anglo-Indian contemporaries, the volumes sold in Bengal in $\mathbf{1} 803$ from the estate Charles Thomas Clarke, Esq., defied the expectations set by the stereotypical nabob. Clarke's extensive library boasted works by Locke, Shaftesbury's Characteristics, Voltaire's Universal History, Montesquieu's Spirit of the Laws, Smith's Moral Sentiments and Wealth of Nations, Blackstone's Commentaries, Godwin's Political Justice and Wollstonecraft's French Revolution. ${ }^{55}$

${ }^{52}$ Henry Russell to Charles Russell, 28 June 1810 , Bodleian, MS Eng. lett. d. ${ }^{162}$, fols $5^{\text {o verso- }} 5^{1}$. 'It is a very extensive and complete Collection of Books; and to a Bookworm like me, will be a very great Source of Advantage and Amusement ... besides which it was a kind and handsome Thing to Syndenham to take it off his Hands; and, as I have benefited so much by his Resignation, it is but fair that I should make my having succeeded him as beneficial as I can'.

${ }^{53}$ OIOC, L/AG/34/27/46, 740, 1322.

${ }^{54}$ Lord Minto to Lady Minto, 17 June 1808 , NLS, MS 11063 , 17 June 1808 , fol. 139 .

55 OIOC, L/AG/34/27/30, inventory of Charles Thomas Clarke. For the vogue of popular history in England, see esp. Karen O'Brien, 'The History Market in Eighteenth-Century England', in Isabel Rivers (ed.), Books and Their Readers in 
By the early nineteenth century, works of Enlightenment history and philosophy were increasingly supplemented by books that reflected Anglo-Indians' emergent Romantic sensibilities. The late Lieutenant Douglas's copy of Burke's treatise On the Sublime-a popular text among Anglo-Indian readers-was purchased by Lieutenant Slye at Midnapore in 1802; Doctor Small's estate, sold in May 1803 , included the poems of Ossian and Burns as well as thirty-three volumes of the Encyclopaedia Brittanica. ${ }^{56}$ The library of Lieutenant T. Harriott of the Marines, sold in Bombay in 1813, encompassed Enlightenment treatises, radical politics and Romantic literature. Including Smith's Moral Sentiments, Gibbon's Roman Empire, Godwins's Political Justice and a tract on the Discontents of the Madras Army, it also boasted Scott's 'Lady of the Lake', Maria Edgeworth's Belinda, Charlotte Smith's Old Manor House and the evocatively mis-titled Liasons of Dangerous. ${ }^{57}$ Romantic writings such as these were soon incorporated into the armoury of expatriate pastimes that provided Anglo-Indian men with emotional release from their Oriental exile. When Lieutenant Thomas Walker Baird's goods were sold in 1819 , they included 114 bottles of Madeira, 33 bottles of French claret, 15 bottles of English claret, 19 bottles of brandy, 53 bottles of beer, two Bibles and a volume of Byron's poems. Lieutenant Colonel William Boye likewise appears to have mixed the consolations of Romantic literature with those of the flesh. His library included Byron's poems, Ossian's verse, the Old Manor House, Rob Roy and Waverley as well as a medical text on Venereal Complaints and a Treatise on the Gout..$^{58}$

Letters sent to family by expatriate Anglo-Indians attest to the emotional power wielded by Romantic poetry over men far distant from their friends and kin. John Elliot's chief satisfactions before his marriage to Amelia Casamaijor derived from the pleasures of the table and the hunt, but even he turned to Romantic writings to ward off depression in Madras. 'Pray tell Walter Scott that if it had not been for the Lay of the Last Minstrel I should have been dead of the Blue Devils long ago, but I go travelling over the ground with William Deloraine till I get right again', he wrote to his mother in

Eighteenth-Century England: New Essays (London: Leicester University Press, 2001), pp. $105-33$.

${ }^{56}$ OIOC, L/AG/34/27/3O.

${ }^{57}$ OIOC, L/AG/34/27/389.

${ }^{58} \mathrm{OIOC}, \mathrm{L} / \mathrm{AG} / 34 / 27 / 290$. 
${ }_{1807 .}{ }^{59}$ Charles and Henry Russell were similarly keen readers of Romantic poetry and fiction, although Henry warmed to Byron's poetry only gradually and selectively. 'Some of the Descriptions .... in Childe Harold are strong and true, but the Sentiments are generally either trite, false, or vicious', he opined to his sister in July $1813 \cdot{ }^{60}$ A year later, Henry had come to appreciate Byron's poetic powers, however much he continued to deplore their 'vicious' levelling tendencies. 'I send you some Lines of Lord Byron's which I cut out of a paper today lest you should not have seen them', he wrote to Charles in August. 'I admire the Poetry as much as I abhor the Sentiments'. ${ }^{61}$

Works of Romantic literature were ideal objects for circulation within the gift economy that maintained the social ties of Anglo-Indian family life. Like the miniatures, portraits, sleeve-buttons and strands of hair circulated as mementos of distant or departed kin, volumes of Romantic poetry and fiction were compact, scarce and saturated with emotive sentiments. Henry Russell's correspondence with his father-in-law after Jane's death thus naturally included requests forand analyses of - the latest available Romantic verse. He requested that Casamaijor send him Scott's 'Lady of the Lake' from Madras in May 1811 , and three weeks later wrote impatiently that he had been able to borrow a copy only fleetingly. 'When you do meet with her, pray secure her for me', he beseeched Casamaijor. 'She was in such Request when I saw her at Bombay, that I could get her for only one Night. I gave almost the whole of it to her Company, and was so much pleased with her, that I should be glad to renew our Acquaintance'. ${ }^{62}$ Personified as a desirable woman, Scott's poem was infused with the spirit of the gift. Existing in the market and at the probate auction as a modern commodity, the text also circulated within an affective

${ }^{59}$ John Elliot to Lady Minto, 6 May [1807], NLS, MS 11 o94, fol. 126 verso.

${ }_{60}$ Henry Russell to Caroline Russell, 6 July 1813 , Bodleian, MS Eng. lett. d. 15 , fol. 13 .

${ }^{61}$ Henry Russell to Charles Russell, 11 August 1814, Bodleian, MS Eng. lett. c. 157 , fol. 23 verso. The offending politics of the poem, 'Unpublished Lines (inscribed on the Monument of a favourite Dog) by Lord Byron', contrasted the loyalty of 'the poor Dog, in life the firmest friend' to the machinations of aristocratic men, 'By nature, vile enobl'd but by name' (fol. 24).

${ }^{62}$ Henry Russell to James Casamaijor, 9 May 181 1, Bodleian, MS Eng. lett. d. 162, fol. 191 verso; Henry Russell to James Casamaijor, 1 June 1811 , Bodleian, MS Eng. lett. d. 163 , fol. 3 verso. The production of these texts by Romantic writers was itself caught up in and enabled by a complex gift economy. See Charles Rzepka, Sacramental Commodities: Gift, Text and the Sublime in De Quincey (Amherst: U Mass Press, 1995), esp. chap. 5 . 
economy in which the claims of kin outweighed those of financial cost and the demands of the individual ego were embedded within a web of carefully constructed and sedulously maintained collective social identities, rather than finding free expression in the anonymous marketplace.

$* * * *$

In The Romantic Ethic and the Spirit of Modern Consumerism, Colin Campbell has argued that Western Romanticism 'functioned to stimulate and legitimate that form of autonomous, self-illusory hedonism that underlies modern consumer behaviour'. ${ }^{63}$ The history of gift and commodity exchange in colonial India suggests that this etiology of Romantic consumerism requires substantial revision. To be sure, the letters and inventories of Anglo-Indian men and women attest to the salience of consuming passions in the expatriate community. As individuals, these consumers constructed rich domestic interiors that boasted impressive print collections, lavish wardrobes and surprisingly comprehensive libraries. Probate records demonstrate that Anglo-Indians contributed significantly to the rampant Bibliomania that marked Romantic culture: like elite men in Britain, these expatriates were captivated by the acquisition and display of the books, textiles, trinkets and other manufactured goods that flowed into the ever-expanding Georgian marketplace. ${ }^{64}$

But if probate inventories attest that hedonistic consumerism was commonplace in British India, the private letters of Anglo-Indian families argue powerfully against the autonomy of even hedonistic consumers in the Romantic era. John Elliot and the Russell brothers were well-attuned to the demands of fashion and well-versed in the vagaries of the consumer market. But their approach to material goods reflected their constant consciousness that even modern commodities served social and emotional ends that linked the individual to wider reticulations of kin and clientage. Volumes of Romantic poetry figured in their correspondence as goods that existed simultaneously as gifts

${ }^{63}$ Colin Campbell, The Romantic Ethic and the Spirit of Modern Consumerism (Oxford: Blackwell, 1987), pp. 200-1.

${ }^{64}$ On Romantic bibliomania, see Philip Connell, 'Bibliomania: Book Collecting, Cultural Politics, and the Rise of Literary Heritage in Romantic Britain', Representations, 71 (Summer 2000), pp. 24-47. 
and as commodities. Rendered desirable in part because of their scarcity and cost in public markets, these goods served as modern analogues of the hand-woven textiles and memorial jewelry that linked family members through traditional gift and counter-gift exchanges across space and time in the British empire.

By probing the emotional economies of material objects (including Romantic texts) in Anglo-Indian society, historians can understand more clearly the role played by extended kin groups in constructing the British empire. Scholars now acknowledge the conceptual limitations imposed on British historical sociology by the Cambridge Group's insistence on the dominance of the nuclear family in England, ${ }^{65}$ but the liabilities of extending this problematic model of family life to the British empire remain to be assessed. Both the centrality and the polyvalence of family are constant leitmotifs in Anglo-Indian private correspondence; the concept of the nuclear family-like the concept of the autonomous individual-is inadequate to the task of analysing Anglo-Indian social and economic relations in the era of the consumer revolution. Jack Goody has argued persuasively that mercantile and industrial developments in both Asia and the modern West depended on extended family networks of entrepreneurs and capitalists, rather than upon the individual bankers, merchants and manufacturers celebrated by English historians. Discounting 'ethnocentric notions about the uniqueness of the West', Goody rejects the claim that Europe saw 'an overall shift from the social to the individual, related to the emergence of the small elementary family' ${ }^{6}{ }^{66}$ The family life of the composite Casamaijor-Elliot-Russell clan in Britain and India provides abundant evidence for Goody's argument. Through emotive and strategic gifts, marriages and political alliances these families built Indian fortunes that were, upon their return to Britain, to fuel the late Georgian consumer economy and to feed the Victorian railway boom.

A more comprehensive recognition of the extended family's role in imperial material life will in turn enrich historians' understanding of the ways in which the British conceptualised, wielded and understood

${ }^{65}$ For an intelligent syntheses of this critique, see Leonore Davidoff, Megan Doolittle, Janet Fink and Katherine Holden, The Family Story: Blood, Contract and Intimacy, I830-1960 (London: Longman, 1999), esp. pp. 31-9, and Naomi Tadmor, Family and Friends in Eighteenth-Century England: Household, Kinship, and Patronage (Cambridge: Cambridge University Press, 2001).

${ }^{66}$ Jack Goody, The East in the West (Cambridge, 1996), pp. 192, 203. 
power in colonial India. Dominant interpretations of the British encounter with Indian political culture underline the fundamental incompatibility between the material world views of coloniser and colonised. ${ }^{67}$ Bernardo Michael's analysis of the misinterpretation by early nineteenth-century East India Company officials of Gorkhali (Nepalese) nazrs-honorific gifts that forged bonds of dependency and subservience between donor and recipient-illustrates this pervasive line of reasoning. Michael attributes British officials' inability to comprehend the meaning of these traditional gifts to the governing elite's commitment to modern political principles, to a world view in which 'honour and status were to be maintained through impartiality in public life, impersonality in their dealings with people, and a clear conception of the distinctions between the "public" and the "private" realms of their lives'. ${ }^{68}$ In his authoritative account of the symbolic order that British imperialists sought to impose in nineteenthcentury India, Bernard Cohn similarly highlighted the replacement of indigenous gift-giving ceremonies with a contractual regime of foreign, 'modern' durbars under the Raj. 'What had been, under Indian rulers, a ritual of incorporation now became a ritual marking subordination', Cohn argued, emphasising the dissonance that marked British and indigenous symbolic systems. "By converting what was a form of present-giving and prestation into a kind of "economic exchange", the relationship between British official and Indian subject or ruler became contractual'. ${ }^{69}$ This interpretation meshes easily with an Orientalised understanding of British culture, an analysis in which the unified and modern British 'Self' was distinguished from the backward Indian 'Other'. But it fails to accommodate the hybrid and the collective identities that Anglo-Indians displayed as consumers, as giftgivers and as family members in the Romantic era. The contractual individuals who stalk the secondary literature of the colonial encounter figure only fleetingly in contemporary primary sources that document

67 This dichotomy persists despite repeated and long-standing calls to recognise the slippage that obtained between these categories within imperial domains. See, for example, Ann Stoler, 'Rethinking Colonial Categories: European Communities and the Boundaries of Rule', Comparative Studies in Society and History, 13 (May 1992), pp. 134-61.

${ }^{68}$ Bernardo A. Michael, 'When Soldiers and Statesmen Meet: "Ethnographic Moments" on the Frontiers of Empire, 1800-15', in Gordon (ed.), Robes of Honour, p. 89 .

${ }^{69}$ Cohn, 'Representing Authority', p. 172. 
imperial family life. To understand the cultural dynamics of political domination, historians must attend more fully to the antinomies of colonial culture, replacing simplistic stereotypes of the modern British individual with more complex models of social persons, individuals that is who were immersed-like their Indian contemporaries-in collective kin obligations that were expressed through the body by the exchange of gifts, commodities and other signifying artifacts. 
